\title{
Improved dynamic performance of photovoltaic panel using fuzzy logic-MPPT algorithm
}

\author{
Khalid W. Nasser ${ }^{1}$, Salam J. Yaqoob ${ }^{2}$, Zainab A. Hassoun ${ }^{3}$ \\ ${ }^{1}$ College of Engineering, University of Misan, Iraq \\ ${ }^{2}$ Popular Mobilization, Prime Minister Office, Iraq \\ ${ }^{3}$ The Islamic University -Najaf, Iraq
}

\begin{tabular}{l} 
Article Info \\
\hline Article history: \\
Received Apr 12, 2020 \\
Revised Jun 15, 2020 \\
Accepted Jul 8, 2020 \\
\hline
\end{tabular}

\section{Keywords:}

Fuzzy logic FL-MPPT

Fuzzy logic technique

Maximum power point tracking and the photovoltaic panel

\begin{abstract}
The nonlinear characteristics and intense credence dependence of photovoltaic (PV) panel on the solar irradiance and ambient temperature demonstrate important challenges for researchers in the PV panel topic. To overcome these problems, the maximum power point tracking (MPPT) controller is needed which can improve the PV panel efficiency. In other words, for maximum efficiency, the MPPT controller can help to extract the optimal and overall available output power from the PV panel at different output load conditions. Fuzzy logic (FL) is one of the strongest techniques in the extracting of MPP in the PV panel since it has several advantages; robust; no requirement to have an accurate mathematical model, and works with imprecise inputs. Therefore, in this paper, fuzzy logic (FL-MPPT) has been designed and simulated to improve dynamic performance PV panel at different solar irradiance and then increased the efficiency. Therefore, "MATLAB/Simulink software" has been used to build the proposed algorithm and the simulation results have been adequate as well. Besides, a robust FL-MPPT algorithm has been presented with high dynamic performance under different weather conditions. Finally, the proposed algorithm has a quicker response and less oscillatory comparison of the conventional algorithms in the subject of extracting the maximum PV power
\end{abstract}

This is an open access article under the CC BY-SA license.

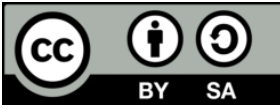

\section{Corresponding Author:}

Khalid W. Nasser

College of Engineering, University of Misan, Iraq

Email: Khalid.waleed@uomisan.edu.iq

\section{INTRODUCTION}

In recent years, renewable energy sources such as wind, solar, wave, tidal powers are environmentally clean, therefore they receiving very strong emphasis throughout the world [1]. The renewable energy harvested by the solar photovoltaic (PV) system is the major source that used today due to it has the simplification of the installation and less mechanical support requirements [2, 3]. The major disadvantages of a PV system are relatively high manufacturing costs and low efficiency (about 9-18\%). Since it is necessary to operate a PV system at the MPP under varying environmental conditions. When a PV system works at this point, the highest possible efficiency is achieved. However, a dc-dc converter and their control algorithms are integrated with a PV panel or system to extract the maximum power continuously under any circumstance [4]. Thus, current-voltage (I-V) and power-voltage (P-V) characteristics of a PV panel are affected by conditions of solar irradiance and ambient temperature. The voltage and current of a PV panel should be controlled to track the maximum power. Many MPPT techniques have been proposed and practiced in recent years [5-7]. The large number of techniques proposed can make it difficult to select the best technique to adopt when implementing a PV application. 
The output power of the PV panel depends mainly on the solar irradiance and temperature. For this reason, any increase in PV panel temperature, the voltage of the PV panel decreases, while the current increases slightly. The resultant effect reduces PV power value. On the other hand, when solar irradiance is increased, the PV panel current is more increased; which is proportional directly to solar irradiance, while the PV voltage exposes little change [8]. Today, the conventional MPPT algorithms such as incremental conductance (INC) algorithm [9, 10], Hill Climbing algorithm [11], and perturbation and observation (P\&O) algorithm [12-14] are known and very simple in implementation, but they have problems such as lower efficiency and oscillations in tracking the maximum power from the PV panel. Several researchers are carried out to solve these problems and improve the performance and then increases the efficiency. Thus, artificial intelligence MPPT algorithms such as an artificial neural networks (ANN), fuzzy logic (FL), and genetic algorithms (GA) are used to improve the efficiency of PV panel [15]. Fuzzy logic MPPT algorithm represented a general technique of expressing linguistic rules, thus it can provide a fast response with simple mathematical non-linear characteristics [16].

Therefore, in this paper fuzzy logic (FL-MPPT ) algorithm for PV panel is presented. The proposed MPPT algorithm tracked the peak point of the PV power with a fast response for different weather conditions. The proposed MPPT unlike the conventional MPPT algorithms where it is tracked the global MPP on the P-V curve or I-V curve depends on the error and the change in error that represents the input variables for the proposed algorithm. The FL-MPPT algorithm has been tested under different solar irradiance to show the performance work successively. Hence, "Matlab/Simulink" software is used to demonstrate the effectiveness and robustness of the proposed MPPT algorithm. Finally, the proposed algorithm has less oscillatory than the conventional algorithms in extracting the maximum power from the PV panel.

\section{MODELING OF PV CELL}

The equivalent circuit is indicated in Figure 1, represents a single-diode PV cell model [17, 18]. The One-diode model is widely used for the most PV cell applications due to its simplicity. In this model the open-circuit voltage and photocurrent source which is approximately equal to the short-circuit current at standard test condition (STC) are the main parameters. The open-circuit voltage is affected by the temperature and the type of the material, while the short-circuit current depends on solar irradiance. Basic equations that represent this ideal PV cell model can be expressed as:

$$
\begin{aligned}
& I_{-} D=I_{-} 0\left[\exp \left(\left(V_{-} p v\right) /\left(\alpha V_{-} T\right)\right)-1\right] \\
& I_{p v}=I_{p h}-I_{D} \\
& V_{p v}=\alpha V_{T} \ln \left[\frac{I_{p h}-I_{p v}}{I_{0}}+1\right]
\end{aligned}
$$

In this model, $\mathrm{I}_{\mathrm{D}}$ is the diode current, $\mathrm{V}_{\mathrm{T}}(=\mathrm{KT} / \mathrm{q})$ is the temperature voltage $\left(25.7 \mathrm{mV}\right.$ at $\left.25^{\circ} \mathrm{C}\right)$. The ideality factor $\alpha$ generally varies from 1 to 5 for the single-diode model. Also, $\mathrm{V}_{\mathrm{pv}}$ is the terminal voltage of PV cell, $\mathrm{I}_{\mathrm{ph}}$ is the source of photo-current source, $\mathrm{I}_{0}$ is the diode reverse saturation current of PV cell, and $\mathrm{I}_{\mathrm{pv}}$ is output PV cell current. Also, $\mathrm{q}$ is the charge of electron $\left(1.60217646 \times 10^{-19} \mathrm{C}\right)$, $\mathrm{K}$ is the Boltzmann constant, $\left(1.3806503 \times 10^{-23} \mathrm{~J} /{ }^{\circ} \mathrm{K}\right)$, the temperature of the $\mathrm{p}-\mathrm{n}$ junction in ${ }^{\circ} \mathrm{K}$ is represented by $\mathrm{T}$.

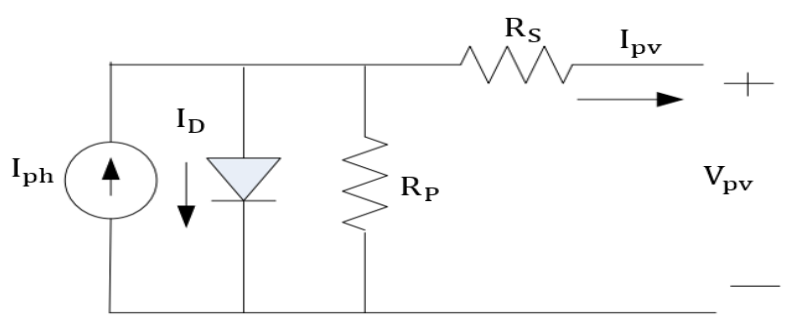

Figure 1. Equivalent circuit of one-diode PV cell model

However, to represent the PV cell or panel as practical form, the series and parallel resistances are added to the equivalent circuit of PV cell model to observe a real PV cell. Thus, the basic (2) for the practical PV cell can be rewritten as [19]. 


$$
I_{p v}=I_{p h}-I_{0}\left[\exp \left(\frac{q\left(V_{p v}+R_{S} I_{p v}\right)}{\alpha K T}\right)-1\right]-\frac{v_{p v}+R_{S} I_{p v}}{R_{P}}
$$

where $R_{P}$ and $R_{S}$ are the parallel and series resistances respectively. All PV panels are provided by datasheet that includes standard test condition parameters as open-circuit voltage $\left(\mathrm{V}_{\mathrm{oc}}\right)$, short circuit current $\left(\mathrm{I}_{\mathrm{Sc}}\right)$, the voltage at MPP $\left(\mathrm{V}_{\mathrm{mpp}}\right)$, the current at MPP $\left(\mathrm{I}_{\mathrm{mpp}}\right)$, the temperature coefficient for the case of open-circuit voltage $\left(\mathrm{K}_{\mathrm{V}}\right)$, the temperature coefficient for case short circuit current $\left(\mathrm{K}_{\mathrm{i}}\right)$ and experimental maximum power $\left(\mathrm{P}_{\mathrm{mpp}}\right)$. These parameters are always puttied in the background of PV panel, which are measured in STC condition for the cell temperature and solar irradiance. On the other hand, $a R_{S}$ and $R_{p}$ are not provided in datasheet, it can be evaluated independently [18]. The source of photocurrent of PV panel $\left(\mathrm{I}_{\mathrm{ph}}\right)$ depends linearly on the solar irradiance falling on the PV panel plane and its influenced by the ambient temperature of PV panel as shown below [18].

$$
\mathrm{I}_{\mathrm{ph}}=\left(\mathrm{I}_{\mathrm{phn}}+\mathrm{K}_{\mathrm{i}} \Delta \mathrm{T}\right) \frac{\mathrm{G}}{\mathrm{G}_{\mathrm{n}}}
$$

where $\mathrm{I}_{\mathrm{phn}}$ is the photo-current source at STC, $\Delta \mathrm{T}=\mathrm{T}-\mathrm{T}_{\mathrm{n}}\left(\mathrm{T}_{\mathrm{n}}=25^{\circ} \mathrm{C}\right)$, $\mathrm{G}$ is the fallen of irradiation on the panel and $G_{n}\left(1000 \mathrm{~W} / \mathrm{m}^{2}\right)$ at STC. In modeling of PV panel, several researchers have assumed that $\mathrm{I}_{\mathrm{phn}}$ of PV panel equal to $\mathrm{I}_{\mathrm{sc}}$, due to real PV panel characteristics. Electrical quantities of the PV panel are in Table 1.

Table 1. Electrical quantities of the SR-60SW PV panel under STC

\begin{tabular}{ccc}
\hline Quantity & Value & Unit \\
\hline $\mathrm{V}_{\mathrm{mpp}}$ & 14.7 & $\mathrm{~V}$ \\
$\mathrm{I}_{\mathrm{mpp}}$ & 4 & $\mathrm{~A}$ \\
$\mathrm{P}_{\mathrm{mpp}}$ & 60 & $\mathrm{~W}$ \\
$\mathrm{~V}_{\mathrm{oc}}$ & 19.26 & $\mathrm{~V}$ \\
$\mathrm{I}_{\mathrm{sc}}$ & 4.55 & $\mathrm{~A}$ \\
$\mathrm{~K}_{\mathrm{i}}$ & $(0.03 \pm 0.015)$ & percent $/{ }^{\circ} \mathrm{C}$ \\
$\mathrm{K}_{\mathrm{v}}$ & $-(93 \pm 10)$ & $\mathrm{mV} /{ }^{\circ} \mathrm{C}$ \\
$\mathrm{N}_{\mathrm{S}}$ & 36 & - \\
\hline
\end{tabular}

\section{ANALYSIS OF DC-DC BOOST CONVERTER}

The proposed system diagram with the FL-MPPT algorithm is indicated in Figure 2. The dc-dc boost converter is used to obtain the maximum power point from the PV panel by changing its duty cycle according to the fuzzy logic (FL) MPPT algorithm which is described in section four. The boost converter is designed according to the steady-state equations in continuous conduction mode (CCM) due to have the best performance and simple design. The boost circuit is adopted under CCM with an ideal circuit (current through the switches at OFF state is zero and drop voltage across the switches at ON state is zero). In CCM operation, the inductor current $I_{L}$ flows continuously and does not reach zero. If a steady state condition exists, the relationship between the input PV voltage and output voltage can be derived from inductor current as shown below $[19,20]$ :

$$
\frac{V_{\text {in }}-V_{\text {out }}}{L} T_{\text {ON }}=\frac{V_{\text {out }}}{L} T_{\text {OFF }}
$$

where $T_{O N}$ is the switch ON time and $T_{O F F}$ is the switch OFF time. By using the duty cycle fact $D=T_{O N} / T$, where $T$ is the total switching period which is equal to $\left(T_{O N}+T_{O F F}\right.$, then the (6) can be rewritten as:

$$
V_{\text {out }}=D V_{\text {in }}
$$

In addition, the duty ratio can be written as:

$$
D=1-\frac{V_{\text {in }}}{V_{\text {out }}}
$$

Thus, the output current can be written as:

$$
I_{\text {out }}=\frac{I_{\text {in }}}{D}
$$


Therefore, the input current for the boost converter can be written as:

$I_{\text {in }}=D I_{\text {out }}$

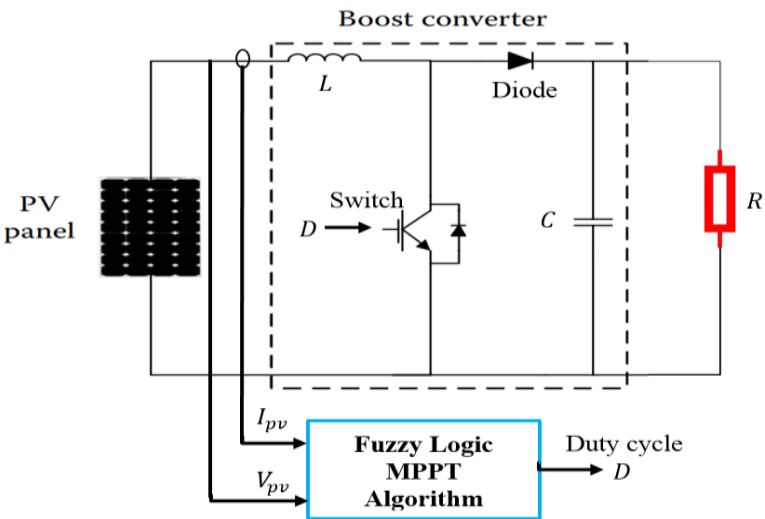

Figure 2. The proposed system diagram with fuzzy logic MPPT algorithm

From (7) and (10), the equivalent input resistance $R_{\text {in }}$ or the resistance that is seen by the PV panel can be written as [20]:

$$
R_{\text {in }}=\frac{R}{D^{2}}
$$

where $R$ is the load resistance. However, from (11) $R_{\text {in }}$ depends on the duty cycle and load resistance, where the duty cycle $D$ changes from 0 to 1 . The operating point of PV panel characteristics is calculated by the intersection of the $\mathrm{I}-\mathrm{V}$ curve with the load line with a slope of $I / V=1 / R$. According to the changing the value of the load resistance, the MPP point moved on the I-V curve. If the load resistance in optimal value, the PV panel operates in maximum power point at point MPP and then the peak power is delivered to the load where optimal resistance is equal to $R_{o p t}=V_{m p p} / I_{m p p}$. In the PV panel operation, the fill factor and maximum efficiency are important quantities that limited the work state of the PV panel, where a fill factor is the ratio of the maximum power produced by the PV panel to the product of $I_{s c}$ and $V_{o c}$ [20]. The fill factor can be expressed by:

$$
F F=\frac{I_{m p} V_{m p}}{I_{s c} V_{o c}}
$$

Efficiency depends on the solar spectrum intensity of solar irradiance and cell temperature. To improve the PV panel efficiency with absorbed a maximum amount of power, the MPPT is used gradually expanded by increasing power demand. For this reason, in this work, a robust efficient fuzzy logic FL-MPPT algorithm is presented.

\section{FUZZY LOGIC MPPT ALGORITHM}

Many advantages can be achieved by using Fuzzy logic such as nonlinearities, not needing a mathematical modeling and working with imprecise inputs $[15,16,21]$. Thus, it has received increased interest in MPPT applications [22-25]. The FL algorithm consists of four units: fuzzification unit, a rule base unit, an inference engine, and a defuzzification unit. The FL-MPPT algorithm has two inputs variables are the error $\mathrm{E}$ and the change in the error $\triangle \mathrm{E}$. On the other hand, FL-MPPT has one output variable, which represents the change in the duty ratio value of boost converter $\Delta \mathrm{D}$. The following equation represents the input variables for FL-controller algorithm.

$$
\mathrm{E}=\frac{\mathrm{P}_{\text {in }}(\mathrm{k})-\mathrm{P}_{\text {in }}(\mathrm{k}-1)}{\mathrm{V}_{\text {in }}(\mathrm{k})-\mathrm{V}_{\text {in }}(\mathrm{k}-1)}=\frac{\Delta \mathrm{P}_{\text {in }}}{\Delta \mathrm{V}_{\text {in }}}=\frac{\Delta \mathrm{I}_{\text {in }}}{\Delta \mathrm{V}_{\text {in }}}+\frac{\mathrm{I}_{\text {in }}}{\mathrm{V}_{\text {in }}}
$$

where $P_{\text {in }}(k)$ and $V_{\text {in }}(k)$ are the power and voltage of the PV panel, respectively: 


$$
\Delta \mathrm{E}=\mathrm{E}_{\mathrm{in}}(\mathrm{k})-\mathrm{E}_{\mathrm{in}}(\mathrm{k}-1)
$$

With two input variables of $\mathrm{E}$ and $\triangle \mathrm{E}$, FL-MPPT decides the next operating point depending on the used membership functions and a rule table. The error $\mathrm{E}$ gives information about how far the current operating point is from that of the MPP, while the input $\Delta \mathrm{E}$ represents how fast the operating points in moving towards or far from the MPP. If the error value is more than zero the algorithm changes the duty cycle to rise the voltage until reaches a maximum power, if the error value less than zero the algorithm changes the duty cycle to decrease the voltage until reaches a maximum power again. However, five different fuzzy levels are used for inputs and output variables (negative big NB, negative small NS, zero Z, positive small PS, and positive big PB). Resulting, the proposed FL algorithm for MPPT will be controlled by 25 different rules as presented in Table 2 . The crisp value of the change in $\Delta \mathrm{D}$ should be added to the previous value of the duty cycle and the resultant value is delivered to the switch of the boost converter.

Table 2. Proposed fuzzy rules table

\begin{tabular}{cccccc}
\hline $\mathrm{E} / \Delta \mathrm{E}$ & $\mathrm{NB}$ & $\mathrm{NS}$ & $\mathrm{ZE}$ & $\mathrm{PS}$ & $\mathrm{PB}$ \\
\hline $\mathrm{NB}$ & $\mathrm{ZE}$ & $\mathrm{ZE}$ & $\mathrm{NB}$ & $\mathrm{NB}$ & $\mathrm{NB}$ \\
$\mathrm{NS}$ & $\mathrm{ZE}$ & $\mathrm{ZE}$ & $\mathrm{NS}$ & $\mathrm{NS}$ & $\mathrm{NS}$ \\
$\mathrm{ZE}$ & $\mathrm{NS}$ & $\mathrm{ZE}$ & $\mathrm{ZE}$ & $\mathrm{ZE}$ & $\mathrm{PS}$ \\
$\mathrm{PS}$ & $\mathrm{PS}$ & $\mathrm{PS}$ & $\mathrm{PS}$ & $\mathrm{ZE}$ & $\mathrm{ZE}$ \\
$\mathrm{PB}$ & $\mathrm{PB}$ & $\mathrm{PB}$ & $\mathrm{PB}$ & $\mathrm{ZE}$ & ZE \\
\hline
\end{tabular}

\section{SIMULATION RESULTS}

The proposed PV system is implemented in "Matlab/Simulink" software as presented in Figure 3. It consists of three units; the PV panel model, the dc-dc boost converter circuit, and the FL-MPPT algorithm. The PV panel model has been built according to the mathematical model equations as presented in section two. While the boost converter is built depends on the electrical circuit that shown in Figure 2.

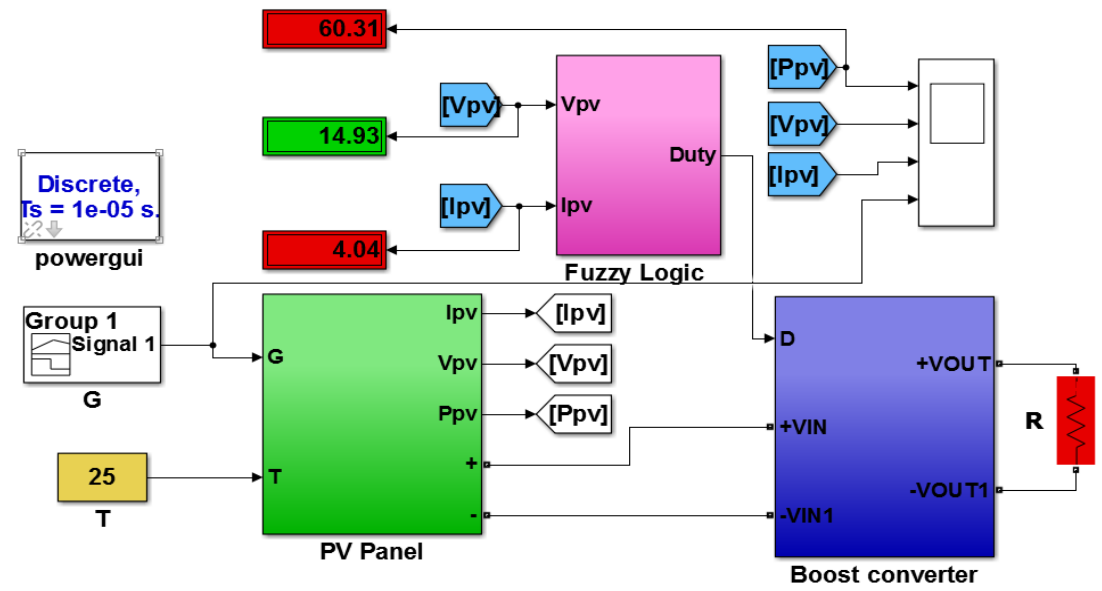

Figure 3. Proposed PV system with FL-MPPT algorithm

Furthermore, the representation of FL-MPPT algorithm has simulated with measured the voltage and current of the PV panel as inputs, the error and the change in error are computed, and it fed to the fuzzy logic controller to provide the optimal PWM signal to the switch of the boost converter. And, by change the duty cycle, the optimal input resistance is achieved with remain the load resistance is constant for $R=$ $3.67 \Omega$. Hence, the maximum power from the PV panel is obtained. Furthermore, an adaptive FL is used to tune the memberships (MFs) and rule-base table to obtain the optimum performance. Thus, triangular membership functions are built to minimize computation processes. The MFs for the input and output variables are indicated in Figure 4.

Furthermore, the PV panel that operated without the MPPT algorithm has lower efficiency and it depends on the weather conditions only such as higher radiation and lower cell temperature. For this reason, the dynamic performance at different weather conditions of the PV panel can be improved by using the 
MPPT algorithm as presented in this paper. The proposed FL-MPPT algorithm is tested under constant temperature $T=25^{\circ} \mathrm{C}$ and different solar irradiance levels as presented in Figure 5.
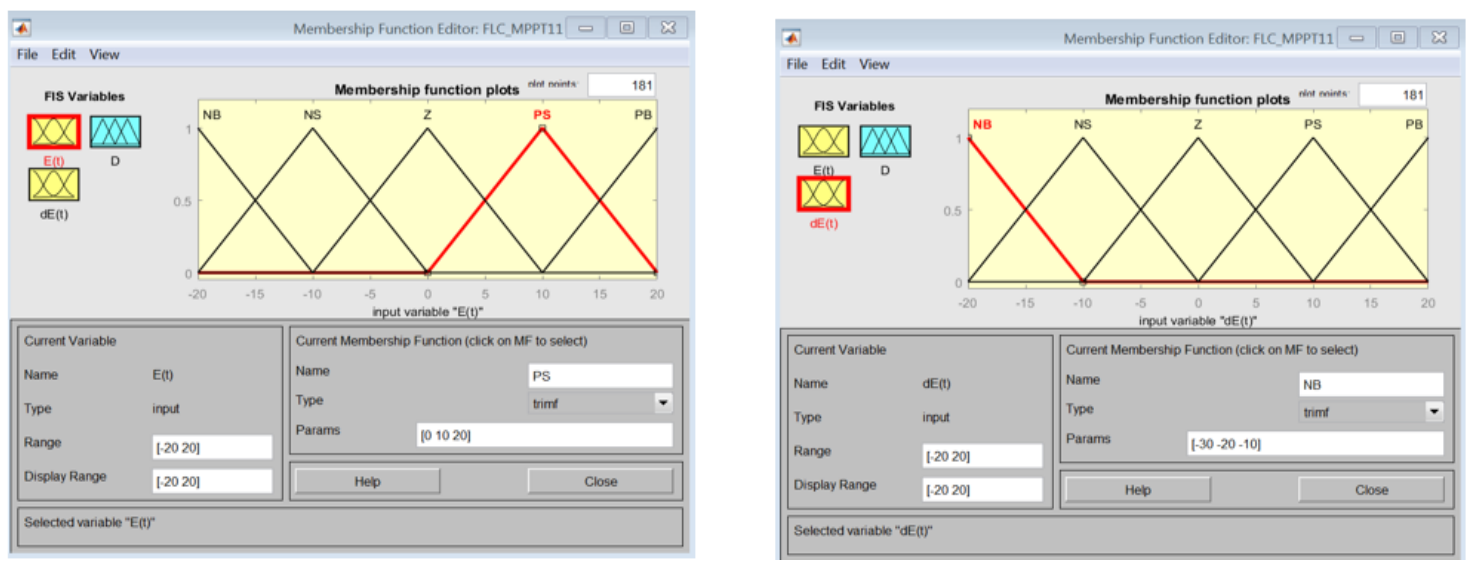

(a)

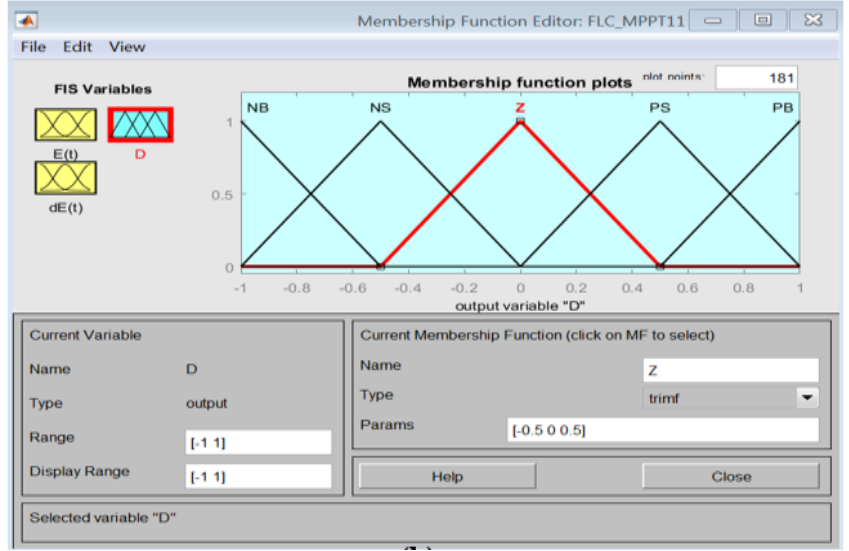

(b)

Figure 4. The membership functions (a) input variables $\mathrm{E}$ and $\Delta \mathrm{E}$ (b) output variable $\mathrm{D}$
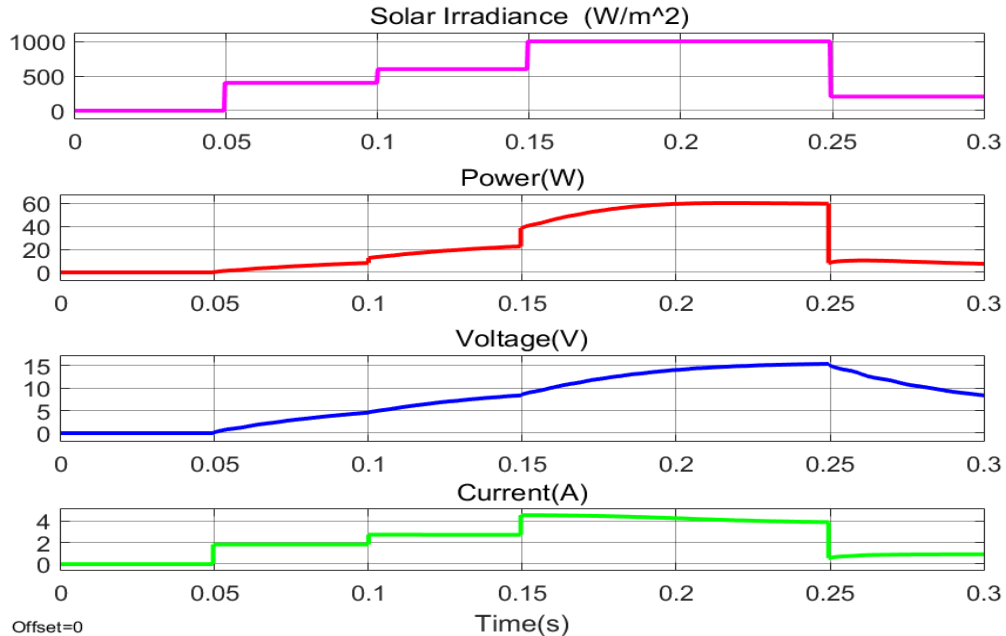

Figure 5. Simulation results of the PV system with FL-MPPT algorithm under different irradiance and constant temperature $T=25^{\circ} \mathrm{C}$ 
From these results, the PV power is dependent on solar irradiance; if irradiance is higher, the output power from the PV is high according to the voltage and current values. Moreover, the proposed FL-MPPT algorithm is compared with the other MPPT algorithms, such as incremental conductance (INC), and perturbation and observation $(\mathrm{P} \& \mathrm{O})$ to test the performance under different irradiance as shown in Figure 6. Figure 7 shows the output power of the PV panel under FL-MPPT, P\&O, and INC algorithms under. The results demonstrate that the $\mathrm{P} \& \mathrm{O}$ algorithm exhibits a slow response in low irradiance level, compared the other algorithms, but a fast response in higher irradiance depending on the theoretical power calculation. The oscillation in $\mathrm{P} \& \mathrm{O}$ is large after steady-state operation. While INC algorithm has an acceptable response in different irradiance levels with little oscillation. On the other hand, the proposed FL-MPPT algorithm has a quicker response and less oscillatory than the other algorithms.

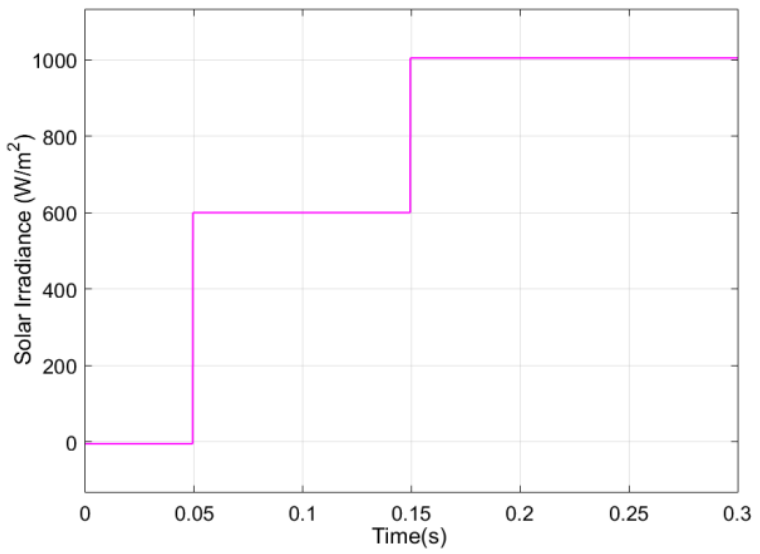

Figure 6. Solar irradiance level under "Matlab/Simulink" software

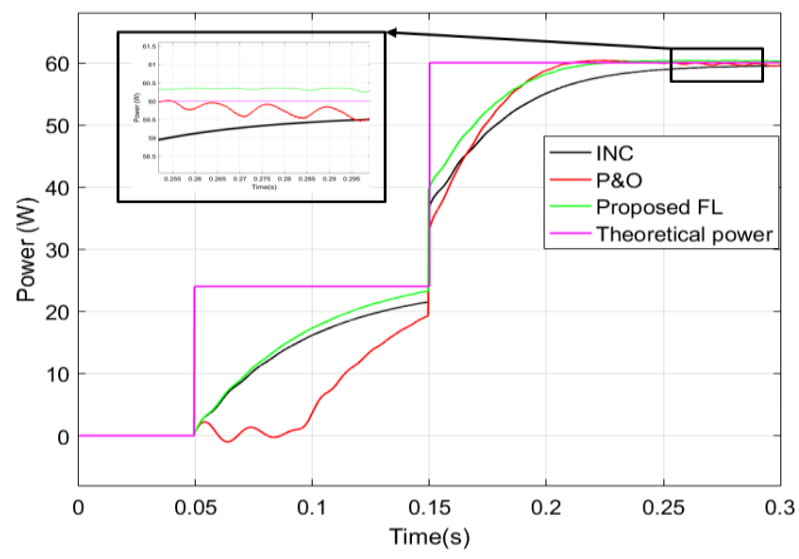

Figure 7. Output power under FL-MPPT, P\&O and INC algorithms under different irradiance

\section{CONCLUSION}

In this paper, a fuzzy logic (FL) maximum power point tracking (MPPT) algorithm is presented to improve the dynamic performance of the PV panel and extracted the global MPP of the PV panel. The single diode PV cell model is used based on mathematical equations of its electrical equivalent circuit. Besides, the dc-dc boost converter is integrated with the PV model to build the FL-MPPT algorithm. The electrical circuit of the boost converter is described, and its equations used to shown the relationship between the load resistance, duty cycle, and the input equivalent resistance of the PV panel. Furthermore, the FL-MPPT algorithm has been implemented by "Matlab/Simulink". The results exhibit that the proposed FL-MPPT algorithm can obtain the optimum MPP under different weather conditions. Finally, the proposed MPPT algorithm has a quicker response and less oscillatory than the conventional algorithms in extracting the maximum power.

\section{REFERENCES}

[1] V. Quaschning, "Understanding Renewable Energy Systems," Earthscan, London, 2005.

[2] A. H. Ali, H. S. Hamad and A. A. Abdulrazzaq, "Performance Investigation of Grid Connected Photovoltaic System Modeling Based on MATLAB Simulation," International Journal of Electrical and Computer Engineering (IJECE), vol. 8, no. 6, pp. 4847-4854, 2018.

[3] H. Sharma, et al., "Modeling and Simulation of Off-Grid Power Generation System Using Photovoltaic," TELKOMNIKA (Telecommunication Computing Electronics and Control), vol. 13, no. 3, pp. 418-424, 2015.

[4] J. Zhao, X. Zhou, Y. Ma, and W. Liu "A Novel Maximum Power Point Tracking Strategy Based on Optimal Voltage Control for Photovoltaic Systems Under Variable Environmental Conditions," Solar Energy, vol. 122, pp. 640-649, 2015.

[5] R. Shun-cheung Yeung, Henry Shu-hung Chung, Norman Chung-fai Tse, and Steve Tzu-hsiung Chuang, "A Global MPPT Algorithm for Existing PV System Mitigating Suboptimal Operating Conditions,” Solar Energy, vol. 141, pp. 145-158, 2017.

[6] J. P. Ram, T. S. Babu, and N. Rajasekar "A Comprehensive Review on Solar PV Maximum Power Point Tracking techniques," Renewable and Sustainable Energy Reviews, vol. 67, pp. 826-847, 2017.

[7] A. Gupta, Y. K. Chauhan, and R. K Pachauri. "A Comparative Investigation of Maximum Power Point Tracking Methods for Solar PV System,” Solar energy, vol. 136, pp. 236-253, 2016. 
[8] J. Jung and S. Ahmed, "Model construction of single crystalline photovoltaic panels for real-time simulation," 2010 IEEE Energy Conversion Congress and Exposition, Atlanta, GA, 2010, pp. 342-349, doi: 10.1109/ECCE.2010.5618015.

[9] R. Faraji, A. Rouholamini, H. R. Naji, R. Fadaeinedjad and M. R. Chavoshian, "FPGA-based real time incremental conductance maximum power point tracking controller for photovoltaic systems," in IET Power Electronics, vol. 7, no. 5, pp. 1294-1304, 2014. doi: 10.1049/iet-pel.2013.0603.

[10] M. Kaouane, B. Akkila, and A. Cheriti, "Implementation of Incremental-conductance MPPT Algorithm In a Photovoltaic Conversion System based on DC-DC ZETA Converter," IEEE, 8th International Conference on Modelling, Identification and Control (ICMIC), 2016., https://ieexplore.ieee.org/document/7804184?denied.

[11] N. Pellet, F. Giordano, M. Ibrahim Dar, G. Zakeeruddin, S. M., Maier, and M. Grätzel, "Hill Climbing Hysteresis of Perovskite-based Solar Cells: a Maximum Power Point Tracking Investigation," Progress in Photovoltaics: Research and Applications, vol. 25, no. 11, pp. 942-950, 2017.

[12] A. Rozana, and Awang Jusoh, "An Enhanced P\&O Checking Algorithm MPPT for High Tracking Efficiency of Partially Shaded PV Module," Solar Energy, vol. 163, pp. 570-580, 2018.

[13] S. Motahhir, A. El Ghzizal, S. Sebti, A. Derouich, and A. Ghzizal, "Proposal and Implementation of a Novel Perturb and Observe Algorithm Using Embedded Software," IEEE 3rd International Renewable and Sustainable Energy Conference, pp.1-5, 2015.

[14] Saleh, Ameer L., Adel A. Obed, Zainab A. Hassoun, Salam J. Yaqoob, "Modeling and Simulation of A Low Cost Perturb\& Observe and Incremental Conductance MPPT Techniques In Proteus Software Based on Flyback Converter," IOP Conference Series: Materials Science and Engineering. vol. 881. no. 1. IOP Publishing, 2020.

[15] M. Kermadi, and El M. Berkouk, "Artificial intelligence-based Maximum Power Point Tracking Controllers for Photovoltaic Systems: Comparative study," Renewable and Sustainable Energy Reviews, vol. 69, pp. 369-386, 2017.

[16] Lubis, A. J., Susanto, E., Sunarya, U., "Implementation of Maximum Power Point Tracking on Photovoltaic Using Fuzzy Logic Algorithm,” TELKOMNIKA (Telecommunication Computing Electronics and Control), vol. 13, no. 1, pp. 32-40, 2015.

[17] V. L. Brano, A. Orioli, G. Ciulla and A. D. Gangi, "An Improved Five-parameter Model for Photovoltaic Modules," Solar Energy Materials and Solar Cells, vol. 94, no. 8, pp. 354-371, 2010.

[18] Salam J. Yaqoob, and Adel A. Obed, "Modeling, Simulation and Implementation of Photovoltaic Panel Model by Proteus Software Based on High Accuracy Two-diode Model," Journal of Techniques, vol. 1, no. 1. pp. 39-51, 2019.

[19] M. E. Basoglu and B. Cakir, "Comparisons of MPPT Performances of Isolated and Non-isolated DC-DC Converters by using A New Approach," Renewable and Sustainable Energy Reviews, vol. 60, pp. 1100-1113, 2016.

[20] A. Khaligh and Omer C. Onar, "Energy Harvesting Solar, Wind, and Ocean Energy Conversion Systems," Boca Raton: CRC Press, 2010.

[21] L. Farah, A. Haddouche, A. Haddouche, "Comparison Between Proposed Fuzzy Logic and ANFIS for MPPT Control for Photovoltaic System," International Journal of Power Electronics and Drive Systems (IJPEDS), vol. 11, no. 2, pp. 1065-1073, 2020.

[22] Z. Cheng, H. Yang and Y. Sun, "FPGA-based PV systems fuzzy MPPT control algorithm," 2010 Seventh International Conference on Fuzzy Systems and Knowledge Discovery, Yantai, 2010, pp. 1244-1248. doi: 10.1109/FSKD.2010.5569127.

[23] B. Tarek, D. Said and M. E. H. Benbouzid, "Maximum Power Point Tracking Control for Photovoltaic System Using Adaptive Neuro- Fuzzy "ANFIS"," 2013 Eighth International Conference and Exhibition on Ecological Vehicles and Renewable Energies (EVER), Monte Carlo, pp. 1-7, 2013. doi: 10.1109/EVER.2013.6521559.

[24] L. Reznik, "Fuzzy Controllers," Newnes, 1st edition, 1997.

[25] T. Esram and P. L. Chapman, "Comparison of Photovoltaic Array Maximum Power Point Tracking Techniques," in IEEE Transactions on Energy Conversion, vol. 22, no. 2, pp. 439-449, 2007. doi: 10.1109/TEC.2006.874230. 